\title{
Pseudozyma hubeiensis sp. nov. and Pseudozyma shanxiensis sp. nov., novel ustilaginomycetous anamorphic yeast species from plant leaves
}

\author{
Qi-Ming Wang, Jian-Hua Jia and Feng-Yan Bai \\ Systematic Mycology and Lichenology Laboratory, Institute of Microbiology, Chinese Academy \\ of Sciences, Beijing 100080, China
}

Correspondence

Feng-Yan Bai

baify@im.ac.cn

\begin{abstract}
Among basidiomycetous yeast strains isolated from wilting leaves of various plants in China, two groups of Pseudozyma strains were distinguished from the others by morphological and physiological characterization. Molecular taxonomic analysis based on sequencing of the large subunit (26S) rRNA gene D1/D2 domain and internal transcribed spacer (ITS) region confirmed that the two groups represent two novel species. They are proposed as Pseudozyma hubeiensis sp. nov. (type strain WS $6.4^{\top}=A S 2.2493^{\top}=$ CBS $10077^{\top}$ ) and Pseudozyma shanxiensis sp. nov. (type strain $\mathrm{SH} 64^{\top}=\mathrm{AS} 2.2523^{\top}=\mathrm{CBS} 10075^{\top}$ ). The phylogenetic relationships of the novel species with described Pseudozyma species and related ustilagomycetous teleomorphs were analysed based on the combined sequences of ITS and D1/D2. The phenotypic diagnosis of $P$ seudozyma was emended because of the negative inositol assimilation reaction of $P$. hubeiensis sp. nov., which was closely related to the type species of the genus, Pseudozyma prolifica.
\end{abstract}

The anamorphic yeast-like species of Pseudozyma belong to the Ustilaginales, as suggested by morphological comparison (Boekhout, 1987) and molecular analysis (Begerow \& Bauer, 2000; Boekhout, 1995; Boekhout et al., 1995; Fell et al., 2000). Seven species were included in the genus by Boekhout \& Fell (1998). Two more species from the blood of patients were described by Sugita et al. (2003). During a survey of basidiomycetous yeasts living on plant leaves in China, a dozen Pseudozyma strains were isolated. Among them, two groups represented by four strains were distinguished from others based on morphological and physiological characterization. Molecular taxonomic analysis based on sequencing of the large subunit (26S) rRNA gene D1/D2 domain and internal transcribed spacer (ITS) region indicated that the two groups represent two novel species.

The strains studied were isolated from wilting plant leaves by using the ballistoconidia-fall method as described by Nakase \& Takashima (1993). Strains $\mathrm{SH} 48$ and $\mathrm{SH} 64^{\mathrm{T}}$ were respectively isolated from Rhododendron oroedoxa Franch. and Quercus mongolica Fisch. ex Ledeb. collected in Taigu, Shanxi Province, and strains WS 4.3.4 and WS 6.4 ${ }^{\mathrm{T}}$ were respectively isolated from Litsea sp. and Magnolia denudata Desr. collected in Wuhan, Hubei Province.

Abbreviation: ITS, internal transcribed spacer.

The GenBank/EMBL/DDBJ accession numbers for the ITS region sequences of strains WS $6.4^{\top}$ and $\mathrm{SH} 64^{\top}$ are D0008954 and D0.008956 and those for the 26S rRNA gene D1/D2 domain sequences are D0008953 and D0008955, respectively.
Most of the morphological, physiological and biochemical characteristics were examined according to standard methods (Yarrow, 1998). Extraction, purification and identification of ubiquinones were carried out according to Yamada \& Kondo (1973). Assimilation of nitrogen compounds was investigated on solid media with starved inocula (Nakase \& Suzuki, 1986).

Nuclear DNA was extracted by using the method of Makimura et al. (1994). Sequences of the ITS (including the $5 \cdot 8 \mathrm{~S}$ rRNA gene) and the 26 rRNA gene D1/D2 domain were determined by methods described previously (Bai et al., 2002). Sequences were aligned with the CLUSTAL $X$ program (Thompson et al., 1997). Phylogenetic trees were constructed from evolutionary distance data calculated from Kimura's two-parameter model (Kimura, 1980) by using the neighbour-joining method (Saitou \& Nei, 1987). Bootstrap analyses (Felsenstein, 1985) were performed from 1000 random resamplings.

\section{Phenotypic characterization}

Though strains SH 48, SH $64^{\mathrm{T}}$, WS 4.3.4 and WS $6.4^{\mathrm{T}}$ were isolated by a method for selective isolation of ballistoconidiumforming yeasts, they did not form forcibly discharged conidia on agar plates. The non-ballistoconidium-forming yeast strains that were frequently isolated using this method usually belonged to Rhodotorula or Cryptococcus. However, the morphological characters of the four strains studied were not typical of these two genera. The positive diazonium blue B and urease reactions showed their basidiomycetous nature. They did not 
produce extracellular starch-like compounds and their major ubiquinone was Q-10. On agar media, they formed yeast-like colonies fringed with pseudohyphae at the margin and produced fusiform blastoconidia by budding on short sterigmalike stalks. Sexual structures were not observed in cultures of single strains or in mating tests. The characteristic colony and blastoconidium morphology suggest that they belong to the genus Pseudozyma as defined by Boekhout (1995) and Boekhout \& Fell (1998). The four strains can be classified into two groups by morphological characters. Strains WS 4.3.4 and WS $6.4^{\mathrm{T}}$ form whitish colonies and predominantly cylindrical cells, whereas strains $\mathrm{SH} 48$ and $\mathrm{SH} 64^{\mathrm{T}}$ formed brownishyellow colonies and predominantly apiculate cells.

\section{Sequence analysis}

The two groups represented by $\mathrm{SH} 64^{\mathrm{T}}$ and WS $6.4^{\mathrm{T}}$ recognized from morphological characterization were confirmed by D1/D2 and ITS sequence comparison. The strains within each of the two groups have identical D1/D2 and ITS sequences. They were clustered in the Ustilaginales clade as defined by Begerow \& Bauer (2000) and Fell et al. (2000) in the tree drawn from D1/D2 sequences (data not shown). The sequence analysis confirmed the assignment of the strains studied to the genus Pseudozyma. Within this genus, SH $64^{\mathrm{T}}$ and WS $6.4^{\mathrm{T}}$ were most closely related to Pseudozyma fusiformata and Pseudozyma prolifica, respectively. Strain SH $64^{\mathrm{T}}$ differed from $P$. fusiformata by 9 $(1.5 \%)$ substitutions in the D1/D2 regions and more than $20 \%$ mismatches in the ITS region. Strain WS $6.4^{\mathrm{T}}$ differed from P. prolifica by $11(1.9 \%)$ substitutions in the D1/D2 region and more than $10 \%$ mismatches in the ITS region. The sequence comparison indicated that strains SH $64^{\mathrm{T}}$ and WS $6.4^{\mathrm{T}}$ represent two novel Pseudozyma species, for which the names Pseudozyma shanxiensis sp. nov. and Pseudozyma hubeiensis sp. nov. are proposed.

The phylogenetic relationships of the novel species with described Pseudozyma species and related teleomorphs of the Ustilaginales were further analysed based on the combined sequences of the ITS and D1/D2 regions (Fig. 1). Selection of the reference teleomorphs was based on Begerow \& Bauer (2000) and Stoll et al. (2005).

P. shanxiensis sp. nov. was located in the Ustilago sensu stricto group of the Ustilago sensu lato clade (Stoll et al.,

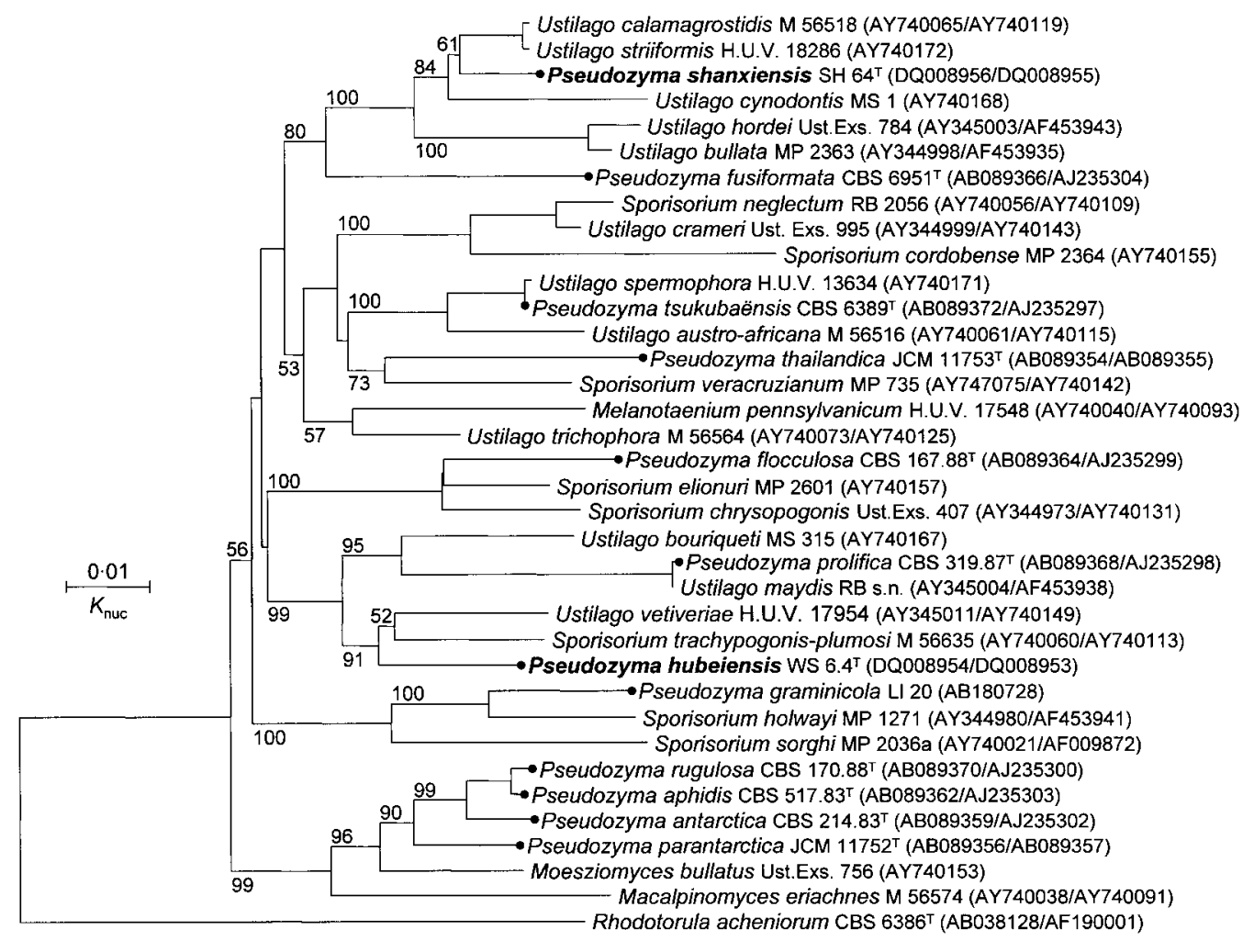

Fig. 1. Phylogenetic tree drawn from neighbour-joining analysis of the combined sequences of the ITS region (including the 5.8S rRNA gene) and the 26S rRNA gene D1/D2 domain, depicting the relationships of the two novel Pseudozyma species with described species of the genus and related ustilagomycetous teleomorphs. Rhodotorula acheniorum is designated the outgroup. Lines ending in dots indicate the positions of Pseudozyma species. Bootstrap percentages over $50 \%$ from 1000 bootstrap replicates are shown. Reference sequences were retrieved from GenBank under the accession numbers indicated; single accession numbers represent sequences that cover both regions. 
2005). The closest teleomorphic relatives of this species were Ustilago striiformis and Ustilago calamagrostidis (Fig. 1). The latter two species differed from each other by only one substitution in each of D1/D2 and ITS regions, implying their conspecificity, as pointed out by Stoll et al. (2005). P. shanxiensis $\mathrm{sp}$. nov. differed from the latter two by $2-3$ substitutions in the D1/D2 region and 18 substitutions and 12 indels in the ITS region, suggesting that the novel species may not be the anamorph of the Ustilago species. P. fusiformata was located on a basal branch of this group.

$P$. hubeiensis sp. nov. and the type species of the genus, $P$. prolifica, were clustered in the Ustilago maydis group of the Sporisorium clade (Stoll et al., 2005). P. hubeiensis sp. nov. was most closely related to Sporisorium trachypogonisplumosi and Ustilago vetiveriae (Fig. 1). It differed from the latter two species by $10-11(\sim 1.7 \%)$ substitutions in the D1/D2 region and more than $10 \%$ mismatches in the ITS region. The ITS and D1/D2 sequences of $P$. prolifica differ from those of $U$. maydis strains available in GenBank in 1-3 and 1-2 substitutions, respectively, suggesting that the former is the anamorph of the latter.

The remaining species of Pseudozyma were clustered in other different groups with different ustilaginomycetous teleomorphs (Fig. 1). Pseudozyma tsukubaënsis and Pseudozyma thailandica were closely related with the species in the Ustilago-Sporisorium clade of Stoll et al. (2005). The anamorph-teleomorph relationship between P. tsukubaënsis and Ustilago spermophora suggested by Begerow \& Bauer (2000) based on D1/D2 sequences was supported by ITS sequence comparison in the present study. They differed by only 1 substitution in this region. Pseudozyma graminicola, which has not been formally described, and Pseudozyma flocculosa are located in the Sporisorium 1 and Sporisorium 2 groups, respectively, of the Sporisorium clade (Stoll et al., 2005). The four other Pseudozyma species formed a wellsupported clade together with Moesziomyces bullatus and Macalpinomyces eriachnes (Fig. 1).

\section{Emendation of the diagnosis of Pseudozyma}

According to the current definition of Pseudozyma, one of the diagnostic phenotypic criteria of the genus is the positive reaction for assimilation of inositol (Boekhout \& Fell, 1998). However, the two strains of $P$. hubeiensis sp. nov. can not assimilate this compound. Phylogenetically, P. hubeiensis sp. nov. is more closely related to the type species $P$. prolifica than to the other described species of the genus. Therefore, the positive inositol assimilation reaction should be deleted from the diagnosis of the genus.

\section{Latin diagnosis of Pseudozyma hubeiensis Bai \& Wang sp. nov.}

In YM (Difco) liquido post dies 5 ad $20^{\circ} \mathrm{C}$, cellulae vegetativae cylindratae, $2 \cdot 0-3 \cdot 7 \times 5 \cdot 0-10 \cdot 0 \mu \mathrm{m}$, singulae aut binae. Annulus, pellicula et sedimentum formantur. In agaro YM post unum mensem ad $20^{\circ} \mathrm{C}$, cultura albidus-cremea, glabra vel rugosa, non-nitida, butyracea, margine glabra aut lobulatae. Pseudomycelia formantur. Fermentatio nulla. Glucosum, galactosum, saccharosum, maltosum, cellobiosum, trehalosum, lactosum, melibiosum, raffinosum, melezitosum, amylum solubile (lente et exigue), D-xylosum, L-arabinosum, D-arabinosum, D-ribosum, D-glucosaminum, glycerolum, erythritolum, ribitolum, D-mannitolum, glucitolum, methyl $\alpha$-D-glucosidum, acidum succinicum et hexadecanum assimilantur at non L-sorbosum, inulin, L-rhamnosum, methanolum, ethanolum, galactitolum, salicinum, acidum DLlacticum, acidum citricum nec inositolum. Ammonium sulfatum, kalium nitricum, natrum nitrosum, L-lysinum, ethylaminum et cadaverinum assimilantur. Ad crescentiam vitaminum non necessarium est. Maxima temperatura crescentiae: $36-37^{\circ} \mathrm{C}$. Materia amyloidea iodophila non formantur. Urea finditur. Diazonium caeruleum B positivum. Ubiquinonum majus: Q-10. Typus: isolatus ex folio Magnolia denudata Desr., WS $6.4^{\mathrm{T}}$, depositus in collectione China General Microbiological Culture Collection Center, Academia Sinica (AS $2.2493^{\mathrm{T}}$ ).

\section{Description of Pseudozyma hubeiensis Bai \& Wang sp. nov.}

Pseudozyma hubeiensis (hu.bei.en'sis. N.L. fem. adj. hubeiensis of Hubei, referring to the geographical origin of the type strain).

In YM broth, after 5 days at $20^{\circ} \mathrm{C}$, cells are mostly cylindrical, $2 \cdot 0-3 \cdot 7 \times 5 \cdot 0-10 \cdot 0 \mu \mathrm{m}$ (Fig. 2a), single or in pairs. Budding is polar on short stalks. Sediment, a ring and a pellicle are formed. After 1 month at $20^{\circ} \mathrm{C}$, sediment, a ring and a pellicle are present. On YM agar, after 1 month at $20^{\circ} \mathrm{C}$, the streak culture is whitish to cream, butyrous, dull, smooth or somewhat wrinkled. The margin is entire or somewhat eroded. In Dalmau plate culture on cornmeal agar, pseudohyphae are formed. Fermentation of glucose is negative. Glucose, galactose, sucrose, maltose, cellobiose, trehalose, lactose, melibiose, raffinose, melezitose, soluble starch (delayed and weak), D-xylose, L-arabinose, Darabinose, D-ribose, D-glucosamine, glycerol, erythritol, ribitol, D-mannitol, D-glucitol, methyl $\alpha$-D-glucoside, succinic acid and hexadecane are assimilated. L-Sorbose, inulin, L-rhamnose, methanol, ethanol, galactitol, salicin, DL-lactic acid, citric acid and inositol are not assimilated. Ammonium sulfate, potassium nitrate, sodium nitrite, L-lysine, ethylamine hydrochloride and cadaverine dihydrochloride are all assimilated. Maximum growth temperature is $36-37^{\circ} \mathrm{C}$. Growth in vitamin-free medium is positive. Starch-like substances are not produced. Growth on $50 \%$ $(\mathrm{w} / \mathrm{w})$ glucose/yeast extract agar is negative. Urease activity is positive. Diazonium blue $\mathrm{B}$ reaction is positive. The major ubiquinone is $\mathrm{Q}-10$.

The type strain, WS $6.4^{\mathrm{T}}$, was isolated from a wilting leaf of Magnolia denudata Desr. collected in Hubei Province, China, in July 2002. This strain has been deposited in the China General Microbiological Culture Collection Center 


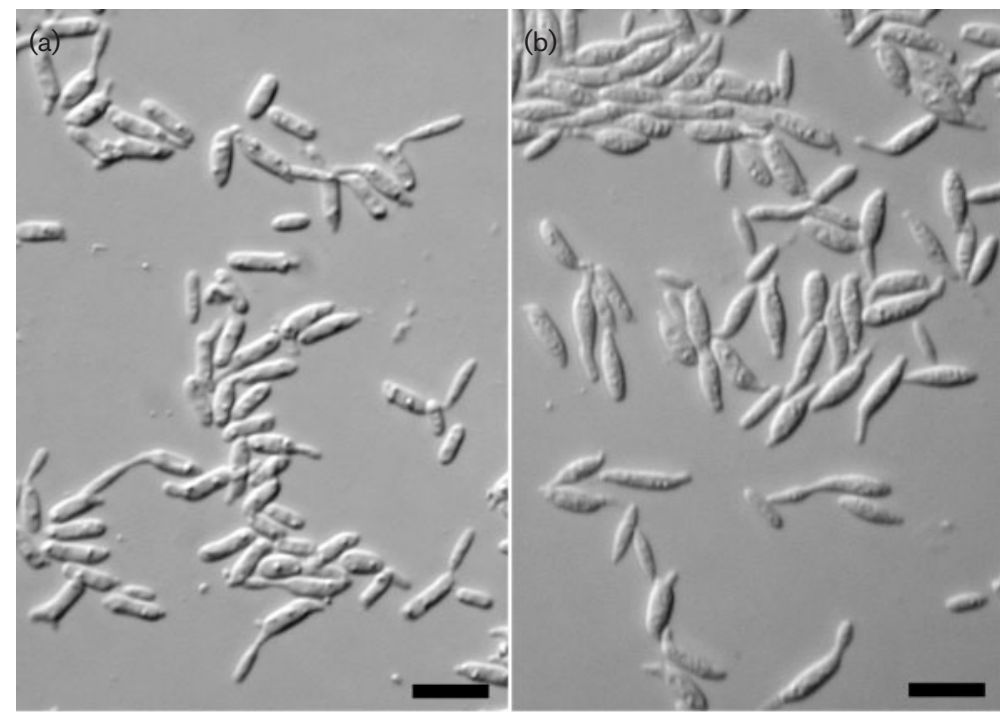

Fig. 2. Vegetative cells of Pseudozyma hubeiensis sp. nov. WS $6.4^{\top}$ (a) and Pseudozyma shanxiensis sp. nov. $\mathrm{SH} 64^{\top}$ (b) grown in $\mathrm{YM}$ broth for 5 days at $20^{\circ} \mathrm{C}$. Bars, $10 \mu \mathrm{m}$.

(CGMCC), Academia Sinica, Beijing, China, as AS $2.2493^{\mathrm{T}}$ $\left(=\mathrm{CBS} 10077^{\mathrm{T}}\right)$.

\section{Latin diagnosis of Pseudozyma shanxiensis Bai \& Wang sp. nov.}

In YM (Difco) liquido post dies 5 ad $20^{\circ} \mathrm{C}$, cellulae vegetativae cylindratae aut fuciformes, $1 \cdot 5-3 \cdot 0 \times 5 \cdot 2-10 \cdot 0 \mu \mathrm{m}$, singulae aut binae. Annulus, pellicula et sedimentum formantur. In agaro YM post unum mensem ad $20^{\circ} \mathrm{C}$, cultura flavobrunneus, brunneus, rugosa, non-nitida, butyracea, margine lobulatae. Pseudomycelia formantur. Fermentatio nulla. Glucosum, galactosum, saccharosum, maltosum, trehalosum (vel exigue), lactosum, melibiosum, raffinosum, melezitosum, amylum solubile (vel exigue), D-xylosum, L-arabinosum, Darabinosum (variable), D-ribosum (variable), ethanolum, glycerolum, D-mannitolum (vel exigue), glucitolum (vel exigue), methyl $\alpha$-D-glucosidum, salicinum (variable), acidum succinicum, inositolum (exigue) et hexadecanum assimilantur at non L-sorbosum (vel lente et exigue), cellobiosum, inulin (vel exigue), L-rhamnosum, D-glucosaminum (vel lente et exigue), methanolum, erythritolum, ribitolum (vel lente et exigue), galactitolum, acidum DLlacticum (vel lente et exigue) nec acidum citricum (vel lente et exigue). Ammonium sulfatum, kalium nitricum, natrum nitrosum, L-lysinum, ethylaminum et cadaverinum assimilantur. Ad crescentiam vitaminum non necessarium est. Maxima temperatura crescentiae: $40-41{ }^{\circ} \mathrm{C}$. Materia amyloidea iodophila non formantur. Urea finditur. Diazonium caeruleum B positivum. Ubiquinonum majus: Q-10. Typus: isolatus ex folio Quercus mongolica Fisch. ex Ledeb., $\mathrm{SH} 64^{\mathrm{T}}$, depositus in collectione China General Microbiological Culture Collection Center, Academia Sinica (AS 2.2523 ${ }^{\mathrm{T}}$ ).

\section{Description of Pseudozyma shanxiensis Bai \& Wang sp. nov.}

Pseudozyma shanxiensis (shan.xi.en'sis. N.L. fem. adj. shanxiensis of Shanxi, referring to the geographical origin of the type strain).
In YM broth, after 5 days at $20^{\circ} \mathrm{C}$, cells are fusiform or cylindrical, $1 \cdot 5-3 \cdot 0 \times 5 \cdot 2-10 \cdot 0 \mu \mathrm{m}$ (Fig. 2b), single or in pairs. Budding is polar on short stalks. Sediment and a ring are formed. After 1 month at $20^{\circ} \mathrm{C}$, sediment, a ring and a pellicle are present. On YM agar, after 1 month at $20^{\circ} \mathrm{C}$, the streak culture is brownish-yellow or brownish, butyrous, dull and wrinkled. The margin is eroded. In Dalmau plate culture on cornmeal agar, pseudohyphae are formed. Fermentation of glucose is negative. Glucose, galactose, sucrose, maltose, trehalose (or weak), lactose, melibiose,

Table 1. Physiological characteristics that differentiate the species of the genus Pseudozyma

Species: 1, $P$. hubeiensis sp. nov.; 2, $P$. shanxiensis sp. nov.; 3, $P$. antarctica; 4, P. aphidis; 5, P. flocculosa; 6, P. fusiformata; 7, P. prolifica; 8, P. rugulosa; 9, P. tsukubaensis; 10, P. parantarctica; 11, P. thailandica. Abbreviations: + , positive; L, delayed positive; W, weakly positive; $\mathrm{S}$, slow positive; - , negative; $\mathrm{V}$, variable.

\begin{tabular}{|c|c|c|c|c|c|c|c|c|c|c|c|}
\hline Characteristic & 1 & 2 & 3 & 4 & 5 & 6 & 7 & 8 & 9 & 10 & 11 \\
\hline \multicolumn{12}{|l|}{ Assimilation of: } \\
\hline Galactose & + & + & + & + & S & - & S & + & S & + & + \\
\hline Lactose & + & + & + & + & - & - & + & - & + & + & - \\
\hline Melibiose & + & + & - & + & s & $\mathrm{V}$ & - & s & - & + & + \\
\hline L-Rhamnose & - & - & $\mathrm{V}$ & + & - & - & + & + & - & - & + \\
\hline Ethanol & - & + & + & - & - & + & + & + & + & + & + \\
\hline Erythritol & + & - & + & + & + & S & + & S & + & + & $\mathrm{L}$ \\
\hline D-Mannitol & + &,$+ \mathrm{w}$ & + & + & + & + & + & + & - & + & + \\
\hline D-Glucitol & + &,$+ \mathrm{w}$ & + & + & + & + & + & + & - & + & + \\
\hline Inositol & - & + & + & + & + & + & + & + & + & + & + \\
\hline Ethylamine & + & + & + & + & - & + & + & + & + & - & - \\
\hline L-Lysine & + & + & + & + & + & + & + & + & - & + & + \\
\hline Cadaverine & + & + & + & + & + & + & + & + & + & - & + \\
\hline \multicolumn{12}{|l|}{ Growth at: } \\
\hline $37^{\circ} \mathrm{C}$ & $\mathrm{W}$ & + & - & - & - & - & - & + & - & + & + \\
\hline $40^{\circ} \mathrm{C}$ & - & + & - & - & - & - & - & $\mathrm{W}$ & - & - & - \\
\hline
\end{tabular}


raffinose, melezitose, soluble starch (or weak), D-xylose, L-arabinose, D-arabinose (variable), D-ribose (variable), ethanol, glycerol, D-mannitol (or weak), D-glucitol (or weak), methyl $\alpha$-D-glucoside, salicin (variable), succinic acid, inositol (weak) and hexadecane are assimilated. LSorbose (or delayed and weak), cellobiose, inulin (or weak), L-rhamnose, D-glucosamine (or delayed and weak), methanol, erythritol, ribitol (or delayed and weak), galactitol, DL-lactic acid (or delayed and weak) and citric acid (or delayed and weak) are not assimilated. Ammonium sulfate, potassium nitrate, sodium nitrite, L-lysine, ethylamine hydrochloride and cadaverine dihydrochloride are all assimilated. Maximum growth temperature is $40-41{ }^{\circ} \mathrm{C}$. Growth in vitamin-free medium is positive. Starch-like substances are not produced. Growth on $50 \%(\mathrm{w} / \mathrm{w})$ glucose/yeast extract agar is negative. Urease activity is positive. Diazonium blue B reaction is positive. The major ubiquinone is Q-10.

The type strain, $\mathrm{SH} 64^{\mathrm{T}}$, was isolated from a wilting leaf of Quercus mongolica Fisch. ex Ledeb. collected in Shanxi Province, China, in July 2001. This strain has been deposited in the CGMCC, Academia Sinica, Beijing, China, as AS $2.2523^{\mathrm{T}}\left(=\mathrm{CBS} 10075^{\mathrm{T}}\right)$.

\section{Identification}

In practice, $P$. hubeiensis sp. nov. differs from the other species of the genus by its inability to assimilate inositol. $P$. shanxiensis sp. nov. can be differentiated from the other species of the genus by the assimilation reactions for erythritol, lactose, L-rhamnose and ethanol and the ability to grow at $40{ }^{\circ} \mathrm{C}$ (Table 1$)$.

\section{Acknowledgements}

This study was supported by grants no. 30170002 from the National Natural Science Foundation of China (NSFC) and no. 2004AA227100 of the 863 program from the Ministry of Science and Technology, China.

\section{References}

Bai, F.-Y., Zhao, J.-H., Takashima, M., Jia, J.-H., Boekhout, T. \& Nakase, T. (2002). Reclassification of the Sporobolomyces roseus and the Sporidiobolus pararoseus complexes, with the description of Sporobolomyces phaffii sp. nov. Int J Syst Evol Microbiol 52, 2309-2314.

Begerow, D. \& Bauer, R. (2000). Phylogenetic placements of ustilaginomycetous anamorphs as deduced from nuclear LSU rDNA sequences. Mycol Res 104, 53-60.

Boekhout, T. (1987). Systematics of anamorphs of Ustilaginales (smut fungi) - a preliminary survey. Stud Mycol 30, 137-149.
Boekhout, T. (1995). Pseudozyma Bandoni emend. Boekhout, a genus for yeast-like anamorphs of ustilaginales. J Gen Appl Microbiol 41, 359-366.

Boekhout, T. \& Fell, J. W. (1998). Pseudozyma Bandoni emend. Boekhout, and a comparison with the yeast state of Ustilago maydis (De Candolle) Corda. In The Yeasts, a Taxonomic Study, 4th edn, pp. 790-797. Edited by C. P. Kurtzman \& J. W. Fell. Amsterdam: Elsevier.

Boekhout, T., Fell, J. W. \& O'Donnell, K. (1995). Molecular systematics of some yeast-like anamorphs belonging to the Ustilaginales and Tilletiales. Stud Mycol 38, 175-183.

Fell, J. W., Boekhout, T., Fonseca, A., Scorzetti, G. \& StatzellTallman, A. (2000). Biodiversity and systematics of basidiomycetous yeasts as determined by large-subunit rDNA D1/D2 domain sequence analysis. Int J Syst Evol Microbiol 50, 1351-1371.

Felsenstein, J. (1985). Confidence limits on phylogenies: an approach using the bootstrap. Evolution 39, 783-791.

Kimura, M. (1980). A simple method for estimating evolutionary rate of base substitutions through comparative studies of nucleotide sequences. J Mol Evol 16, 111-120.

Makimura, K., Murayama, Y. S. \& Yamaguchi, H. (1994). Detection of a wide range of medically important fungi by the polymerase chain reaction. J Med Microbiol 40, 358-364.

Nakase, T. \& Suzuki, M. (1986). Bullera megalospora, a new species of yeast forming large ballistospores isolated from dead leaves of Oryza sativa, Miscanthus sinensis, and Sasa sp. in Japan. J Gen Appl Microbiol 32, 225-240.

Nakase, T. \& Takashima, M. (1993). A simple procedure for the high frequency isolation of new taxa of ballistosporous yeasts living on the surfaces of plants. RIKEN Rev 3, 33-34.

Saitou, N. \& Nei, M. (1987). The neighbor-joining method: a new method for reconstructing phylogenetic trees. Mol Biol Evol 4, 406-425.

Stoll, M., Begerow, D. \& Oberwinkler, F. (2005). Molecular phylogeny of Ustilago, Sporisorium, and related taxa based on combined analysis of rDNA sequences. Mycol Res 109, 342-356.

Sugita, T., Takashima, M., Poonwan, N., Mekha, N., Malaithao, K., Thungmauthasawat, B., Prasarn, S., Luangsook, P. \& Kudo, T. (2003). The first isolation ustilaginomycetous anamorphic yeasts, Pseudozyma species, from patients' blood and a description of two new species: P. parantarctica and P. thailandica. Microbiol Immunol 47, 183-190.

Thompson, J. D., Gibson, T. J., Plewniak, F., Jeanmougin, F. \& Higgins, D. G. (1997). The CLUSTAL_X Windows interface: flexible strategies for multiple sequence alignment aided by quality analysis tools. Nucleic Acids Res 25, 4876-4882.

Yamada, Y. \& Kondo, K. (1973). Coenzyme Q system in the classification of the yeast genera Rhodotorula and Cryptococcus and the yeast like genera Sporobolomyces and Rhodosporidium. J Gen Appl Microbiol 19, 59-77.

Yarrow, D. (1998). Methods for the isolation, maintenance and identification of yeasts. In The Yeasts, a Taxonomic Study, 4th edn, pp. 77-100. Edited by C. P. Kurtzman \& J. W. Fell. Amsterdam: Elsevier. 